\title{
ENVIRONMENTAL CONSEQUENCES OF MORAGAHAKANDA DEVELOPMENT PROJECT
}

\author{
DMSHK Ranasinghe \\ Department of Forestry and Environmental Science, \\ University of Sri Jayewardenepura, Nugegoda
}

The Moragahakanda Development Project is an integral component of the 30-year Master plan for the Mahaweli Development Programme and is the last of the reservoirs to be developed.

The project comprise of many cor yjonents; a $63 \mathrm{~m}$ high dam and two smaller saddle dams at Moragahakanda forming a reservoir with full supply level (FSL) of $185 \mathrm{mmsl}$ and area of 29.5 $\mathrm{km} 2$, a $20 \mathrm{MW}$ base power plant incorporated in the dam with a $132 \mathrm{KV}$ transmission line to Habarana, a second diversion tumel from Bowatenna to Lenadora with $25 \mathrm{~m} 3 / \mathrm{s}$ capacity accompanied by improvement of the Huruluwewa Feeder Canal, a branch extension of the Upper Left Bank Canal of the Kacudulla Irrigation Scheme in System D1 to accommodate around 1000 families who would be displaced by the Project.

This paper attempts to review the principle environmental impacts of the proposed project, especially in upstream catchment, reservoir area and the dam, power plant, downstream river and irrigation and settlements. Effects on the environment in the construction phase and operational phase also were taker separately. An environmental management plan had been designed covering all the project components and mitigation measures in the upstream river basin, reservoir area and dam site, dıwnstream river and irrigation areas. 